\title{
Biological parameters and abundance of the razor clam, (Solen brevis), from the Bushehr area of the Persian Gulf
}

\author{
Nassir Niamaimandi \\ Iran Shrimp Research Center ,Bushehr, Iran \\ Email address: \\ nmaimandi@yahoo.com (N. Niamaimandi)
}

To cite this article:

Nassir Niamaimandi. Biological Parameters and Abundance of the Razor Clam, (Solen Brevis), from the Bushehr Area of the Persian Gulf. Agriculture, Forestry and Fisheries. Vol. 1, No. 1, 2012, pp. 1-6. doi: 10.11648/j.aff.20120101.11

\begin{abstract}
Biological parameters were estimated for the razor clam (Solen brevis) sampled from the intertidal zone around Bushehr, Iran. Monthly and periodic quadrat sampling along random transects were conducted from October 2008 to September 2009 to estimate abundance and growth parameters. The estimated abundance of S. brevis ranged from 1.50 (August) to 4.20 (October) clams per $0.25 \mathrm{~m} 2$ (mean 3.25, SD 1.1), while the estimated growth parameters for Lo and K were $120 \mathrm{~mm}$ and 0.7 , respectively. The mean total length ranged from $80.8 \mathrm{~mm}( \pm 10.2)$ in November to $97.6 \mathrm{~mm}( \pm 14.2)$ in July. Natural mortality (M) and maximum age (Tmax) were estimated at 0.26 per year and 4.6 years, respectively. Expansion of the shrimp culture industry along with petroleum exploration activities are believed to be the major factors responsible for the decrease in population size for S. brevis along the coast of Bushehr.
\end{abstract}

Keywords: Biological Parameters, Abundance, Clam, Solen brevis, Bushehr, Persian Gulf

\section{Introduction}

Few studies have been conducted on bivalves from the Persian Gulf. The earliest record identified 17 bivalves' species from the Hormozgan area of Iran (Issel 1865). Later, Martens (1874) identified 119 intertidal species which included the bivalves and gastropods in the Persian Gulf. More recent studies have also focused on shell identification, distribution, growth, and population parameters (Melvill 1940; Biggs 1957; Smyth 1972; Hasan 1994. and Houseinzadeh et al. 2001).

The jacknife razor clam Solen brevis, an edible bivalve known locally as "Melalis", is one of two Solen species common to the eastern Persian Gulf (Hosseinzadeh et al. 2001). Razor clam habitats include stable, fully exposed, surf pounded, broad, flat, uniform, hard and sandy coastal areas (McMillan 1924; Fitch 1953; and Browning 1980). S. brevis is found in the muddy sand substrate, buried vertically at a depth ranging from 5 to $12 \mathrm{~cm}$ with in the intertidal zone of Bushehr province. These razor clams are harvested by inserting a sharpened steel rod downward into the siphon-formed hole of the substrate until the clam is impaled, and then slowly pulling upward.

The local abundance and distribution of S. brevis has decreased to the point whereby some formerly inhabited areas are now devoid of the species. Several prominent factors have been attributed to the population decline. Since the introduction of shrimp culturing in the Bushehr area (1996) the demand for razor clams, as a food source for shrimp, has greatly increased. Further, razor clam meat is a preferential bait type used by the hook and line artisanal fleet targeting demersal fishes. It is believed that these two factors have resulted in the overexploitation of $\mathrm{S}$. brevis. In addition, increased activities by oil companies around Bushehr coastal waters have contributed to the destruction of essential razor clam habitat that, in turn, may have impacted the population size. The objectives of the present study were to estimate abundance, growth, mortality, and maximum age parameters of S. brevis found in the Bushehr coastal area. In addition, some environmental factors were also investigated.

\section{Materials and Methods}

This study was carried out in Bushehr intertidal zone of Iran (from $50^{\circ} 38^{\prime} \mathrm{E}-29^{\circ} 27^{\prime} \mathrm{N}$ to $52^{\circ} 41^{\prime} \mathrm{E}-27^{\circ} 17 \mathrm{~N}$ ), area where water depth ranges from 0.1 to $2.0 \mathrm{~m}$ (Fig. 1). Monthly random sampling transects were conducted in a ziz-zag formation to ensure representative coverage of all shell beds. For each transect, S. brevis were counted and samples collected from two to three quadrats $(0.25 \mathrm{~m} 2)$ during low tide (Fig. 1). 
The effects of seasonality were compared by sampling during mpare seasonal differences, samples for the biomass estimation were collected during warm (August, October, November, and December) and cold (January and February) periods. A total of 20-30 quadrats were sampled each month. The mean number of samples was calculated as the sum of individuals from each quadrat $(\mathrm{X})$, divided by the number of quadrats sampled (n). Standard error (SE) and confidence limits $(\alpha=0.05)$ were also calculated.

Shell length (anterior-posterior axis) was measured to the nearest millimeter using vernier calipers. The values for $\mathrm{K}, \mathrm{L} \infty$ and t0 were estimated with the Bertalanffy (1938) growth equation.

$$
\mathrm{Lt}=\mathrm{L} \infty\left(1-\mathrm{e}-\mathrm{K}\left(\mathrm{t}-\mathrm{t}^{\circ}\right)\right)
$$

Where, Lt is the length at time $t, \mathrm{~L}_{\infty}$ is the asymptotic length, $\mathrm{K}$ is the growth coefficient and t0 is the hypothetical age when the size is zero. The parameters $\mathrm{L}_{\infty}$, $\mathrm{K}$, and $\mathrm{t} 0$ were estimated using LFDA software (version 5). The growth performance index (Ǿ) was calculated using the formula of Pauly and Munro (1984).

$$
\dot{\varnothing}=\ln \mathrm{K}+2 \ln \mathrm{L} \infty
$$

Natural mortality (M) was derived using the method described by Taylor (1960) for bivalves.

$$
\mathrm{M}=2.996 / \mathrm{A} 0.95
$$

Where A0.95 represents the 95th percentile of the asymptotic length. Longevity estimates (Tmax), L $\infty$ and $\mathrm{K}$, were calculated using the inverse of the von Bertalanffy equation (King 2006).

$$
\operatorname{Tmax}=\mathrm{t} 0-(1 / \mathrm{k}) \ln [1-(\mathrm{Li} / \mathrm{L} \infty)]
$$

Where $\mathrm{Li}$ is arbitrarily considered equal to $99 \%$ of the asymptotic length

$$
\mathrm{Tmax}=\mathrm{t} 0-(3 / \mathrm{K})
$$

Over the course of the study, a total of 620 samples were collected for precise measurements of total length $( \pm 1 \mathrm{~mm})$ and weight $( \pm 0.01 \mathrm{~g})$. Parameters of the relationship between length and weight were calculated by regression analysis.

$$
\mathrm{W}=\mathrm{a} * \mathrm{Lb}
$$

Small amounts of bottom sediment were taken from cores (15 centimeters depth) in January to calculate the proportion of sand using the method described by Folk (1980). Salinity and water temperature were also measured during high tide of sampling day.

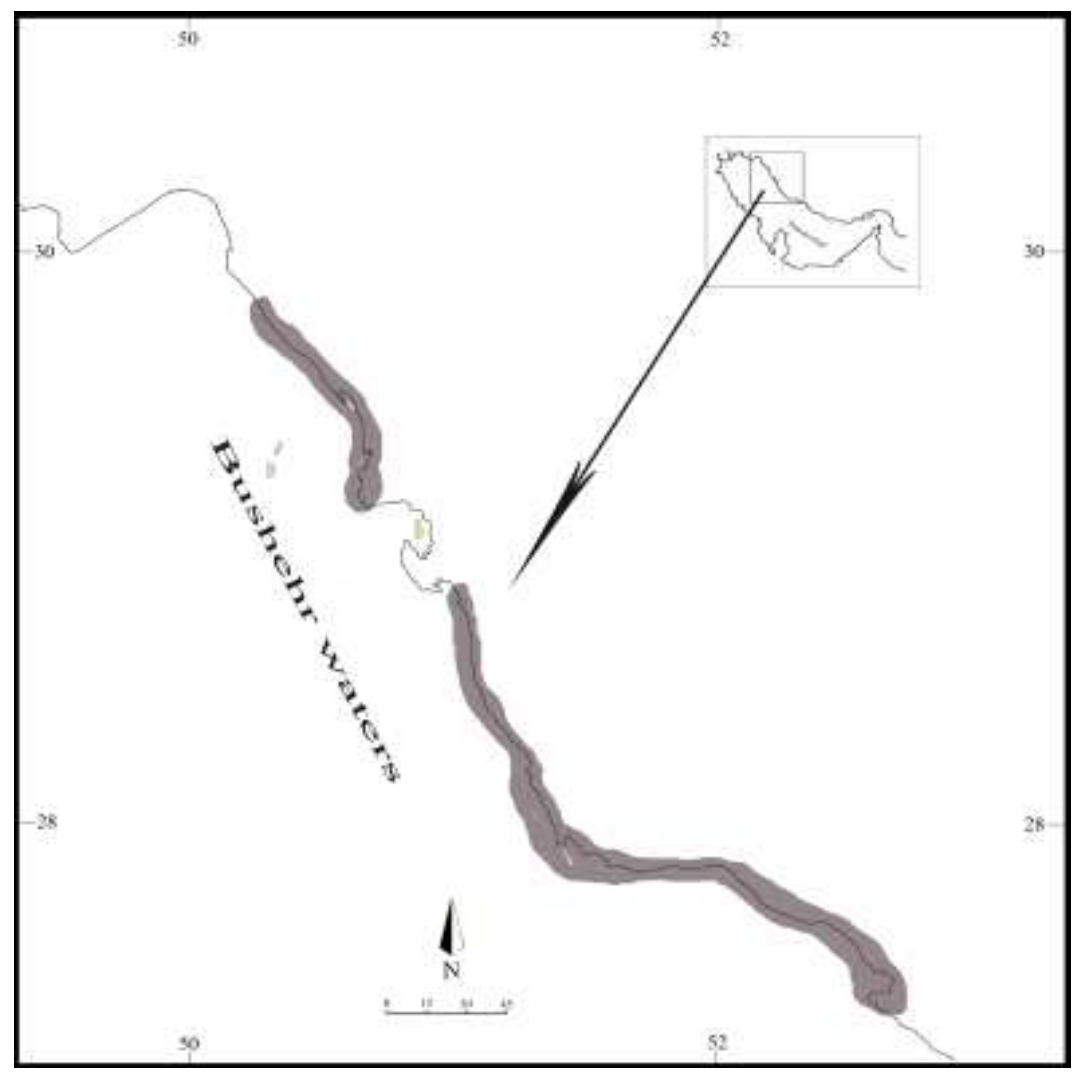

Figure 1. Sampling area for the razor clam Solen brevis from the Bushehr area of the Persian Gulf (2008-09).

\section{Results}

The mean monthly number of $\mathrm{S}$. brevis estimated per quadrat ranged from 1.5 (August) to 4.6 (October). The mean number of individuals per quadrat was 3.25 (SD 1.1, Table 1). 
Table 1. Mean number of Solen brevis individuals per $0.25 \mathrm{~m} 2$ found in Bushehr study area, (Persian Gulf) during period of October 2008 to September 2009.

\begin{tabular}{lll}
\hline Month & No. of Quadrats & Mean No.individuals per quadrat \\
\hline Oct 2008 & 29 & 4.6 \\
Nov 2008 & 21 & 3.4 \\
Dec 2008 & 20 & 4.1 \\
Jan 2009 & 28 & 3.4 \\
Feb 2009 & 27 & 2.5 \\
Aug 2009 & 30 & 1.5 \\
Total & 155 & $3.25( \pm 1.1))$ \\
\hline
\end{tabular}

The estimated growth parameters derived from the Von Bertalanffy equation were: $\mathrm{L} \infty=120 \mathrm{~mm}, \mathrm{~K}=0.7$ year -1 and $\mathrm{t} 0=-0.35$ (Fig. 2), while the estimated index for comparing growth performance $(\dot{\varnothing})$ was in $0.7+2 \ln 120=$ 9.2. The relationship of total length and weight determined by exponential regression (Fig. 3) was: W=0.6912 L 2.96.

Mean total length (Fig. 4) ranged from $(80.8 \mathrm{~mm}$, SD Table 3. Mean of the salinity (PSU) and temperature $\left({ }^{\circ} \mathrm{C}\right)$ measurements of the Bushehr intertidal zone (Persian Gulf) sampled during the period of October 2008 to September 2009.

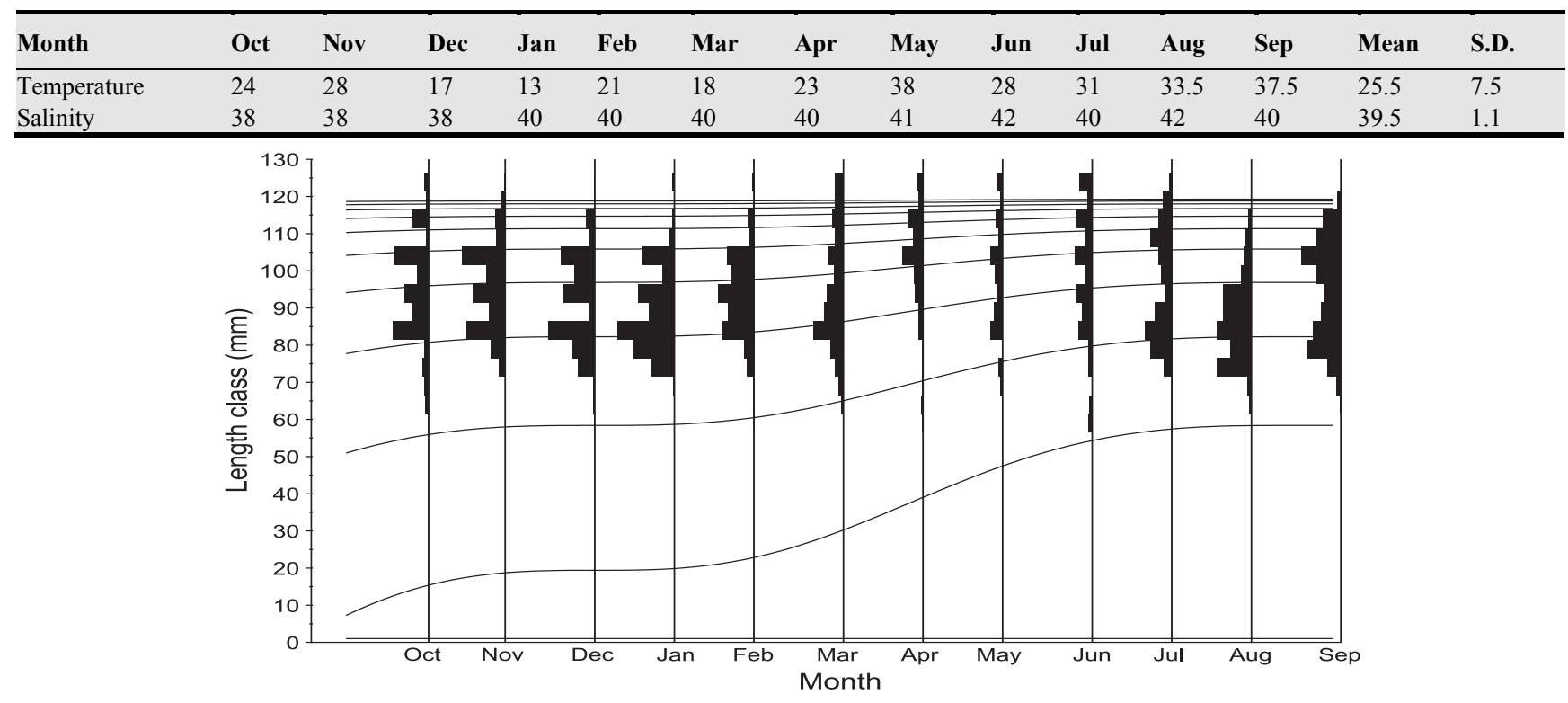

Figure 2. Length frequency curve for Solen brevis in Bushehr waters, Persian Gulf (2008-09). L $\infty=120 \mathrm{~mm}$ K=0.7 year -1 t $0=-0.35$.

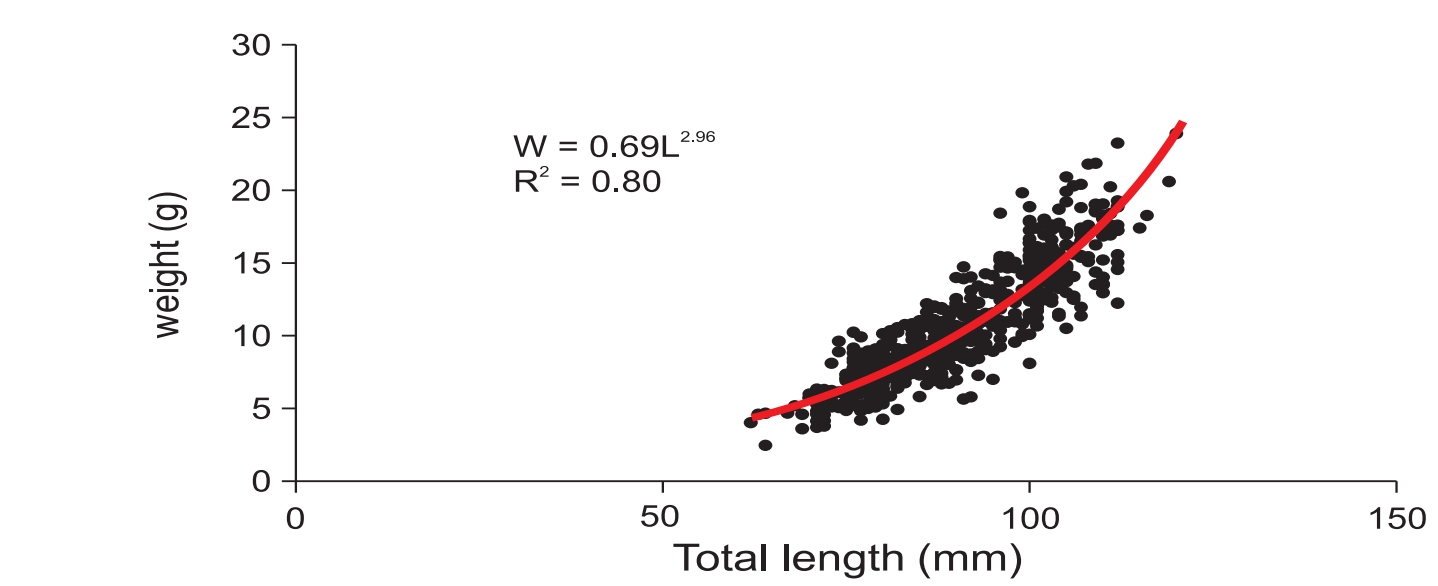

Figure 3. Relationship of total length and weight of Solen brevis in Bushehr waters, Persian Gulf (2008-09).
10.2, November) to (97.6 $\mathrm{mm}$, SD14.2, July). Maximum estimated age $($ Tmax $)$ was $-0.35-(3 / 0.7)=4.6$ year.

The bottom sediment grain sizes (Table 2) consisted of gravel $(>2000 \mu)$, sand $(2000-62.5 \mu)$, silt $(62.5-2.0 \mu)$ and clay $(<2.0 \mu)$.

Table 2. Percentages of bottom sediment particle sizes categorized by weight $(\mu)$ in Bushehr, Persian Gulf (2008-09).

\begin{tabular}{lll}
\hline Sediment type & Particle size $(\boldsymbol{\mu})$ & Percent \\
\hline Clay & $<2.0$ & 9.66 \\
Silt & $2.0-62.5$ & 28.28 \\
Sand & $62.5-2000$ & 61.81 \\
Gravel & $>2000$ & 0.15 \\
\hline
\end{tabular}

Water temperatures ranged from $13{ }^{\circ} \mathrm{C}$ (January) to $38^{\circ} \mathrm{C}$ (May, Table 3), while salinity ranged from 38 psu to 42 psu. The mean value of water temperature and salinity were $25.5^{\circ} \mathrm{C}(\mathrm{SD} 7.5)$ and $39.5 \mathrm{psu}(\mathrm{SD} 1.1)$ respectively. 


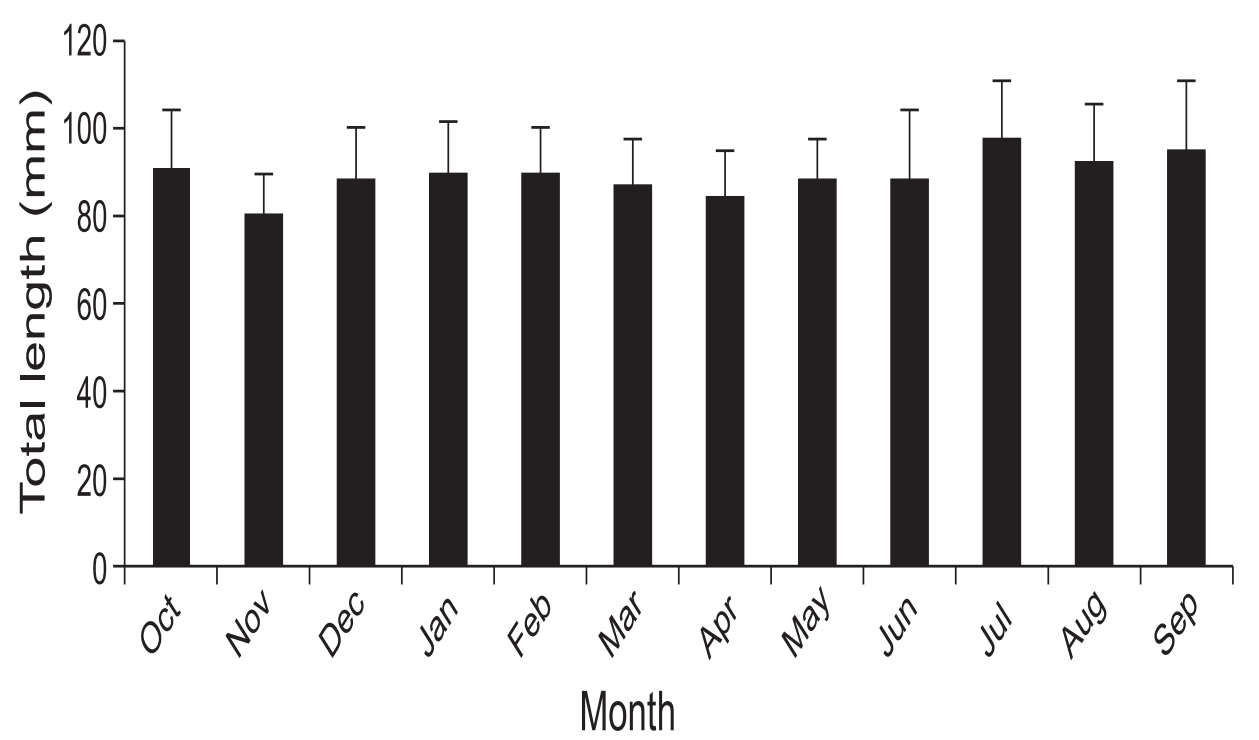

Figure 4. Average total length of Solen brevis $(n=5390)$ sampled from Bushehr waters during the period October 2008 to September 2009.

\section{Discussion}

The estimates from the present study suggest that the growth rate of the $\mathrm{S}$. brevis increases during the warm months (July-November), and is lowest during the cold season (January-March, Fig. 2). Beginning in August, newly recruited $\mathrm{S}$. brevis exhibited a total length mode of $\sim 70 \mathrm{~mm}$. The length-frequency curve also exhibits two cohorts during most months (Fig. 2). In comparison, the mean reported growth rate of razor clams (S. solecurtus) from the Andaman Sea area was $1.2 \mathrm{~mm} / \mathrm{month}$, while the monthly weight gain for ages 6-9 months and 10-37 months were $1.02-1.15 \mathrm{~g}$ and $0.07 \mathrm{~g}$, respectively (Veeravaitaya 2007).

Various techniques have been used to estimate the ages of bivalves. Examples include size frequency distribution analysis (Cerrato 1980), mark and recapture experiments (Gaspar et al. 2004), and analyses of oxygen and carbon isotopic composition (Keller et al. 2002). Annuli formation on the bivalve shell surface has also been used to estimate the growth rate of bivalves (Richardson et al. 1990), although it often suffers from the presence of false growth rings (Keller et al. 2002), or recent rings formed to closely together to allow easy distinction (Richardson 2001).

Maximum age estimates reported for razor clam vary by location, increasing sharply from five years for Pismo Beach, California (Weymouth et al. 1931), to 9-11 years for the Pacific Northwest (McMillan 1924), and 18-19 years for Alaska (Nickerson 1975). In contrast, the maximum age of S. brevis in the present study was lower (4.6 years).

Weymouth et al. (1925) reported that razor clam shells turn translucent prior to spawning. After spawning, the shells lose their translucence and become dark again. In the present study the larger specimens of S. brevis had dark shells. Further, the length-frequency data indicated that large, older clams were predominant in the summer months, while the smallest clams appeared in November. Although our sampling did not include spring months, these two factors suggest that $\mathrm{S}$. brevis spawning in the Bushehr area may occur during this period. In support, the congener $\mathrm{S}$. roseomaculatus is known to spawn in the Persian Gulf during the spring and summer months, peaking in June (Houseinzadeh 2004).

A prominent source of natural mortality for S. brevis in the Bushehr area is predation by fishes of the family Sparidae, specifically Acanthopagrus berda and Sparidentex hasta (Niamaimandi 1991). Seabirds may also prey on the Bushehr population of S. brevis. Although this has not been substantiated, avian predation on razor clams has been documented elsewhere. For example, McMillan (1924) estimated that $>20,000$ seabirds preyed on newly recruited razor clams along Copalis Beach Washington. Also, Tegelberg and Magoon (1969) observed great numbers of shorebirds feeding on razor clams throughout the period of dense set. In the Bushehr study area, recruitment occurs in August (Fig. 2), which is also the period of lowest biomass. Other reports have indicated the highest natural mortality rate for razor clams (99\%) occurs in the initial eight months of age, and the lowest (1\%) for those grouped $>3$ years of age (McMillan, 1924; Nikerson, 1975 and ; Link, 1980).

In the present study most of the substrates inhabited by S. brevis on Bushehr beaches are flat. More than $50 \%$ of the bottom sediments are sand with the grain size $2-0.625 \mathrm{~mm}$ in diameter. The lowest percentage $(0.00015 \%)$ of particles greater than $2 \mathrm{~mm}$ consisted of gravel. The percentage of the total organic matter in the study area was less than 1 percent. A low percentage of organic material in razor clam habitat has also been reported by others (McMillan, 1924). Hirschhorn (1962) described a flat beach-face slope along the coast of Oregon, with small sand grain size $(0.2 \mathrm{~mm})$. In a survey of Alaskan razor clam beaches, Nickerson (1975) reported a uniform substrate with an average grain size of $0.16-0.19 \mathrm{~mm}$, and suggested that productive beaches have a low clay fraction. The densities of these 
Alaskan razor clams were highest on beaches having the lowest percentages $(0.0005 \%$ to $0.85 \%)$ of particles less than $0.005 \mathrm{~mm}$. In comparison, the average sediment grain size for S. Solecurtus habitat in the Andaman Sea was $0.125 \mathrm{~mm}$ (Veeravaitaya, 2007).

Water temperature in the Bushehr study area varied monthly, ranging from $13{ }^{\circ} \mathrm{C}$ to $38^{\circ} \mathrm{C}$ (Table 3). Exposure to high temperatures has been linked to razor clam mortality in laboratory studies. Sayce and Tufts (1971) reported that mortality began around $21^{\circ} \mathrm{C}$, but varied according to absolute temperature and period of exposure. For example, mortality at $21^{\circ} \mathrm{C}$ occurred after $4 \mathrm{~h}$, at $27^{\circ} \mathrm{C}$ after $3 \mathrm{~h}$, at $28{ }^{\circ} \mathrm{C}$ after $2 \mathrm{~h}$, and at $29^{\circ} \mathrm{C}$ after $1 \mathrm{~h}$. Weymouth et al (1925) noted that spawning of razor clams on Washington beaches occurred at $13{ }^{\circ} \mathrm{C}$, while Bourne and Quayle (1970) suggested that spawning might be linked to factors associated with upwelling, tidal cycle, and food availability. Although fluctuations in salinity levels were minimal in the Bushehr study area, other studies suggest that salinity may be a prominent factor affecting the growth and mortality of razor clams. McMillan (1924) reported that clams were killed when salinity was reduced along Washington beaches after heavy rainfall, and Tegelberg (1964) reported that decreased salinity slowed the growth rate of razor clams.

Overexploitation by Bushehr fishers targeting razor clams for bait or cultured shrimp food is believed to be the main factor associated with the decrease of the razor clam population. Environmental degradation resulting from increased petroleum exploration and extraction activities may also have contributed to the decrease, although this is not understood well and warrants further investigation.

\section{Acknowledgements}

This project was funded and supported by Bushehr Fisheries Department (Shilat). Appreciation is extended to the managers of Shilat and Iranian Fisheries Research Organization (IFRO) for their support. The author also thanks A. Ansari, R. Gholamnezhad, K. Khorshidian and G. Izadpenahi for their contributions to this research, and $\mathrm{J}$. Hoolihan for useful comments on the manuscript.

\section{References}

[1] Bertalanffy L Von (1938). A quantitative theory of organic growth (Inquiries on growth laws. II). Human Biol. 10: 181213.

[2] Biggs HEJ (1957) Littoral collection in the Persian Gulf. J. Conch. London, 24: 270-275.

[3] Bourne N and Quayle DB (1970). Breeding and growth of razor clams in the British Columbia. Fish. Res. Board Can. Tech. Rep. 232. 39pp.

[4] Browning RJ (1980) Fisheries of the North Pacific. Alaska Northwest Publ. Co. Anchorage, Alaska. 434 pp.
[5] Cerrato RM (1980) Demographic analysis of bivalve populations. In: Skeletal Growth of Aquatic Organisms Rhoads DC. and Ludz RA (eds). Plenum press, New York, 417-468.

[6] Fitch JE (1953) Common marine bivalves of California. Calif. Fish Game 90: 67-79.

[7] Folk R L (1980) Petrology of Sedimentary Rocks. Hemphill Publishing, Austin, TX. 184pp.

[8] Gaspar MB, Pereira AM, Vasconcelus, P, Monteiro, CC (2004) Age and growth of Chamelea gallina from the Algarve coast (southern Portugal): influence of sea water temperature and gametogenic cycle on growth rate. J. Molluscan Stud. 70: 371-377.

[9] Hasan AK (1994) A taxonomic review of the bivalve and gastropod mollusc fauna along the Saudi intertidal zone of the Arabian [Persian] Gulf. J. Kau. Mar. Sci. Vol 7. Special issue. $245-253$.

[10] Hirschhorn G (1962) Growth and mortality rates of the razor clam (Siliqua patula) on Clatsop beach, Oregon. Fish Comm. Oreg. Contrib. No. 27. 55pp.

[11] Houseinzadeh H, Daghoghi B and Rameshi H. (2001). Atlas of the Persian Gulf mollusks. Iranian Fisheries Research Organization Press. Tehran. 208 pp.

[12] Houseinzadeh H (2004) Reproductive biology of razer clam Solen roseomaculatus in the northern part of the Persian Gulf, Journal of Pajouhesh and Sazandegi 62: 14-20.

[13] Issel A (1865) Catalogo del molluschi raccolti della Missione Italiana in Persia. Mem. Delle realeacademia della scienze di Torino, Ser. 2, 23pp.

[14] Keller N, Del Piaro D and Longinelli A (2002) Isotopic composition, growth rate and biological behavior of Chamellea gallina and Callista chione from the Gulf of Trieste (Italy). Mar. Biol. 140: 9-15.

[15] King M (2006) Fisheries Biology, Assessment and Management. Second edition. Blackwell. Toogoom, Queensland Australia. 377 pp.

[16] Link T (1980) Mortality rates of the razor clam based upon the 1973 tagging study on Gearhart beach. Oreg. Dep. Fish Wildl. Shellfish Invest. Info. Rep.

[17] Martens S (1874) Ueber voderasiatische conchylien nach den sammlugen des prof, Hausnecht cassel. Verlag. Von Theodor Fisher. 102 pp.

[18] McMillan HC (1924) The life history and growth of razor clam. 34th Annu. Rep. Washington Departmentof Fisheries, Olympia. $76 \mathrm{pp}$.

[19] Melvill JC (1940) Description of twenty-three species of gastropoda from the Persian Gulf, Gulf of Oman and Arabian Sea. Proc. Malac. Soc. London, 6. 51-60.

[20] Niamaimandi N (1991) Biological parameters, feeding and spawning of eight demersal species in the Persian Gulf Bushehr waters (In Persian).Tehran, IFRO. Press. 77 pp.

[21] Nickerson RB (1975) A critical analysis of razor clam population in Alaska. Alaska Dept. Fish and game, Juneau. $194 \mathrm{pp}$.

[22] Pauly D and Munro J L (1984) Once more on the growth 
comparison in fish and invertebrates. Fishbyte 2: $21 \mathrm{pp.}$

[23] Richardson CA, Seed, R, Naylor, E (1990) Used of internal growth bands for measuring individual and population growth rates in Mytilus edulis from offshore production platforms, Mar. Ecol. Prog. Ser 66. 259-265.

[24] Richardson CA (2001) Molluses as archives of environmental change. Oceanogr. Mar. Biol. Annu. Rev 39. $103-164$

[25] Sayce CS and Tufts DF (1971) The effect of high water temperature on the razor clam, Siliqua patula. Proc. Natl. Shellfish. Assoc. 62. 31-34.

[26] Smythe K (1972) Marine mollusca from Bahrain Island, Persian Gulf. J. Conch. 491-496.

[27] Taylor CC (1960) Temprature, growth and mortality-the Pacific cockle. Journal du conseil international pour lexploration de la Mar 26. 117-124.
[28] Tegelberg HC (1964) Growth and ring formation of Washington razor clams. Wash. Dep. Fish. Fish. Res. Pap. 2(3). 69-103.

[29] Tegelberg HC and Magoon CD (1969) Growth, survival and some effects of the dence razor clam set in Washington. Proc. Natl. Shellfish. Assoc. 59. 126-135.

[30] Veeravaitaya N (2007) Sustainable harvesting of razer clams along the coast of the. Andaman Sea. Ph.D. proposal. http://www.unepscs.org.

[31] Weymouth FW, McMillin HC and Rich WH (1931) Latitude and relative growth in the razor clam, Siliqua patula. J. Exp. Biol. 8 ( 3 ) : 228 pp.

[32] Weymouth FW and McMillin HC (1929) The relative growth and mortality of pacific razor clam (Siliqua patula, Dixon) and their hearing on the commercial fishery. Fish. Bull. 46. 543-567. 